\title{
Craniofacial Distraction
}

Editor

ROBERTO L. FLORES

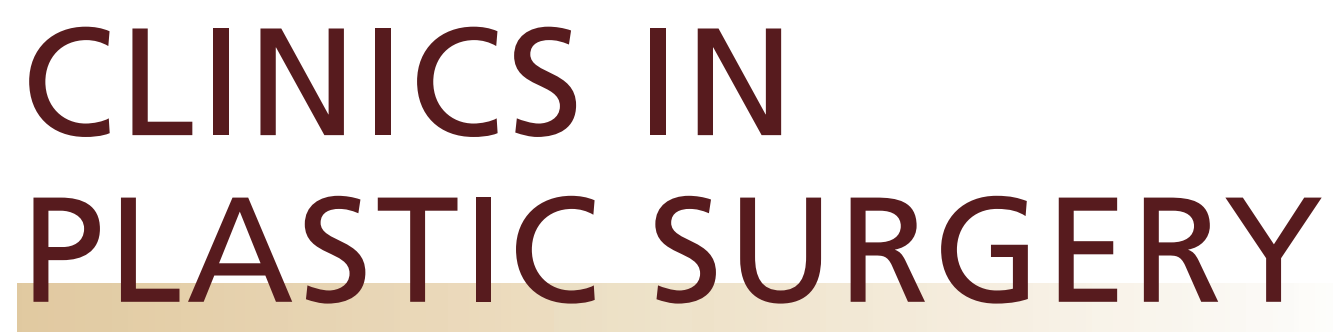

www.plasticsurgery.theclinics.com

July 2021 • Volume 48 • Number 3 